\title{
Significance of Serum Prostate Specific Antigen Levels in Evaluating Prostatic Lesions with Histopathological Correlation
}

\author{
Shruti Amit Deshpande ${ }^{1 *}$, Sabiha A Maimoon ${ }^{2}$ and Sadhana Devendra Mahore ${ }^{3}$ \\ 'Assistant Professor, Department of Pathology, Mamata Medical College, Khammam. Professor, \\ ${ }^{2}$ Department of Pathology, N.K.P.Salve Medical College And Research Centre, Nagpur. Professor and H.O.D., \\ ${ }^{3}$ Department of Pathology, N.K.P.Salve Medical College And Research Centre, Nagpur.
}

\begin{abstract}
Background: Prostate cancer is one of the commonest forms of cancer among men. Serum prostate specific antigen (PSA) used in the diagnosis of prostate cancer is also elevated in other benign and non-malignant diseases of prostate.

Objectives: The objectives of the study were to determine the relationship of serum f(PSA) and t(PSA), its correlation with histopathological findings andto assess the PSA cut off variable in various pathological conditions of prostate with clinical relevance.

Materials and Methods: This study included 141 patients admitted for transurethral resection of prostate and 141 control cases. fPSA was determined on blood samples by sandwich enzymelinkedimmunosorbentassayandtotal PSAby Enzyme Linked Fluroscent Assay method. The samples were processed and stained with haematoxylin and eosin.

Results: The mean t(PSA) values for benign, premalignant and malignant lesions were $10.3 \mathrm{ng} / \mathrm{ml}, 20.36 \mathrm{ng} / \mathrm{ml} \mathrm{and} 75.92 \mathrm{ng} / \mathrm{ml}$ respectively. The mean serum fPSA values for benign, premalignant and malignant lesions were $3.2 \mathrm{ng} / \mathrm{ml}, 9 \mathrm{ng} / \mathrm{ml} \mathrm{and} 13.2 \mathrm{ng} / \mathrm{ml}$ respectively. The cut off value for tPSA was $12.25 \mathrm{ng} / \mathrm{ml}$ and that of fPSA was $9.4 \mathrm{ng} / \mathrm{ml}$. The p value $(<0.0001)$ was highly significant in determiningpremalignant and malignant lesions.
\end{abstract}

Conclusion: Total PSA is raised in premalignant, malignant, inflammatory and benign neoplastic lesions of prostate. In cases where the $\mathrm{t}(\mathrm{PSA})$ values are between four - ten $\mathrm{ng} / \mathrm{ml}, \mathrm{f}(\mathrm{PSA})$ is useful markerin cases of malignancies, which were confirmed on histopathology.

Keywords: Benign Prostatichyperplasia, fPSA, tPSA, Premalignant Lesions, Prostate Cancer.

\section{Introduction}

Prostatic carcinoma is one of the most common cancers and the second most common cause of death due to cancers in male. Also the curative treatments are limited to early stages of the disease, making primary and secondary preventions significant.

Prostate specific antigen (PSA) is highly specific for prostate tissue, but not for prostate cancer, as it can be raised in non-malignant conditions like benign prostatic hyperplasia (BPH), inflammation, diagnostic and surgical procedures also. This may lead to confusion in diagnosis especially in prostate cancer detection programs that use PSA as a screening test. However, of the two forms (free and bound), lower levels of free PSA can improve the sensitivity of cancer detection when total PSA is in the normal range $(<4 \mathrm{ng} / \mathrm{mL})$ and "gray zone" (4.1 to $10 \mathrm{ng} /$ $\mathrm{mL})$. Still, there is only limited data available on this subject. ${ }^{[1,2,3]}$ In our study aim was to find the levels of the two biomarkers (total and free PSA) with their correlation in different prostatic pathology; and to assess the prostate specific antigen (PSA) cut off variable in various pathological conditions of prostate with clinical relevance

\section{Material and Methods}

The present study was carried out for two years in pathology department of tertiary care hospital after prior approval from the ethical committee. The study included 141 patients willing to give informed consent ranging from age 30-90 years, and who were admitted to the surgical ward with history of prostatic or urinary complaints. All Prostatic biopsies obtained from surgery department through transurethral resection were included in our study. We excluded patients who had histopathologically proved metastatic carcinomas to prostate, elevated PSA levels in carcinomas other than prostatic pathology and samples with inadequate prostatic biopsies for histopathological reporting.

Control samples(141) were also taken from the normal healthy volunteers of different age groups having no prostatic or urinary complaints.

Blood samples were taken for measurement of fPSA and tPSA before Trans-Uretheral Resection Of Prostate(TURP), 
and at least a week after digital rectal examination to avoid possible errors caused by the release of PSA from the prostate. The serum samples were stored at $-20^{\circ} \mathrm{C}$ and were tested for fPSA and tPSA. tPSA was estimated by Enzyme Linked Fluroscent Assay (ELFA) method. fPSA was estimated by sandwich Enzyme Linked Immunosorbent Assay (ELISA) method. Clinically, different age wise normal tPSA levels were considered as - 40 to 49 years0 to $2.5 \mathrm{ng} / \mathrm{mL} ; 50$ to 59 years- 0 to $3.5 \mathrm{ng} / \mathrm{mL} ; 60$ to 69 years 0 to $4.5 \mathrm{ng} / \mathrm{mL} ; 70$ to 79 years- 0 to $6.5 \mathrm{ng} / \mathrm{mL}$. The serum fPSA value from 0.4 to $1.3 \mathrm{ng} / \mathrm{ml}$ were considered as normal. ${ }^{[4]}$ The tissue samples were collected after biopsy and TURP were fixed in 10\% formalin, processed routinely and stained with Hematoxylin-Eosin.

The cases were histopathologically categorized as -

I. Benign prostatic hyperplasia without and with inflammation:

This included BPH, chronic prostatitis, acute prostatitis, chronic active prostatitis and nonspecific granulomatous prostatitis.

II Prostatic intraepithelial neoplasia(PIN): This included Low-grade PIN (LGPIN) and High-grade PIN (HGPIN).

III. Prostate Cancer (PCa): This included, Low-grade PCa (LGPCa) and High-grade PCa (HGPCa).

Data analysis was done using Chi-Square test, Fisher exact test, Unpaired t test and ANOVA were ever applicable. The relationship of fPSA with tPSA was determined and its correlation with histopathological findings was established. Receiver Operating Curve (ROC) analysis was done to determine the cut off value for fPSA. P value of $<0.05$ was considered as statistically significant.[fig.1]

\section{Results}

In our study, most of the patients were elderly ( $>60$ years), with average age of 66 years (range 50-82 years). Age-wise distribution showed majority of patients in 60-69 years of age (40\%); followed by $70-79$ years $(38 \%)$ and $50-59$ years $(19 \%)$. Three patients were $>80$ years of age. Similar distribution was also seen in controls.

On histopathological examination, out of the 141 patients, 99 cases $(70.21 \%)$ were of BHP, 19 cases $(13.48 \%)$ of PIN I, 11 cases $(7.80 \%)$ of PIN II, 5 cases $(3.54 \%)$ of PIN III and 7 cases $(4.97 \%)$ of PCa. [fig.2 -6]

The distribution of patients according to normal reference showed that normal $\mathrm{tPSA}(0-4 \mathrm{ng} / \mathrm{ml})$ level present in $43 \%$ of patients with BHP; $3 \%$ in premalignant lesion and nil in prostatic malignancy. Intermediate tPSA $(4-10 \mathrm{ng} / \mathrm{ml})$ level present in $37 \%$ of patient with BHP; $26 \%$ in premalignant lesion and nil in malignancy. High tPSA $(>10$ $\mathrm{ng} / \mathrm{ml}$ ) level present in $21 \%$ of patient with BHP; $71 \%$ in pre-malignant lesion and 100 in malignancy. Statistical analysis showed that significantly higher level of tPSA in prostatic malignancy as compared to benign lesion.[table no.1]

Mean tPSA level in patients of BPH were $10.3 \mathrm{ng} / \mathrm{ml}$ (ranged from $0.23-78.85 \mathrm{ng} / \mathrm{mL}$ ); prostatic intraepithelial neoplasia were $20.36 \mathrm{ng} / \mathrm{ml}$ (ranged from 2.91-82.0 ng/ $\mathrm{mL}$ ); whereas in prostatic cancer were $75.92 \mathrm{ng} / \mathrm{ml}$ (ranged from 12.4-124 $\mathrm{ng} / \mathrm{mL}$ ). Statistical analysis showed that significantly higher level of tPSA in prostatic malignancy as compared to benign lesion $(\mathrm{p}<0.001)$ and prostatic intraepithelial neoplasia $(\mathrm{p}<0.001)$. Significantly higher level of tPSA was seen in prostatic intraepithelial neoplasia as compared to benign lesion $(\mathrm{p}<0.012)$.

Mean fPSA level in patients of BPH were $3.2 \mathrm{ng} / \mathrm{ml}$ (ranged from $0.024 .3 \mathrm{ng} / \mathrm{mL})$; prostatic intraepithelial neoplasia were $9.0 \mathrm{ng} / \mathrm{ml}$ (ranged from 0.90-23.6 ng/mL); whereas in prostatic cancer were $13.5 \mathrm{ng} / \mathrm{ml}$ (ranged from 2.5$22.3 \mathrm{ng} / \mathrm{mL}$ ). Statistical analysis showed that significantly higher level of fPSA in prostatic malignancy as compared to benign lesion $(\mathrm{p}<0.001)$ and prostatic intraepithelial neoplasia $(\mathrm{p}<0.001)$. [table no.2]

Significantly higher level of fPSA was seen in prostatic intraepithelial neoplasia as compared to benign lesion $(\mathrm{p}<0.01)$. The distribution of patients showed that normal fPSA $(0-5 \mathrm{ng} / \mathrm{ml})$ level was present in $85 \%$ of patient with BHP; $61 \%$ in pre-malignant lesion and $14 \%$ in prostatic malignancy. Statistical analysis showed that significantly higher level of fPSA in prostatic malignancy as compared to benign lesion $(\mathrm{p}<0.001)$.

The distribution of patients according to normal reference showed that normal tPSA $(0-4 \mathrm{ng} / \mathrm{ml})$ level present in $43 \%$ of patient with BHP; $4.5 \%$ in LGPIN and nil in HGPIN and prostatic malignancy. Intermediate tPSA (4-10 ng/ml) level present in 37\% of patient with BHP; $36 \%$ in LGPIN; $12.5 \%$ in HGPIN ; and nil in malignancy. High tPSA $(>10$ $\mathrm{ng} / \mathrm{ml})$ level present in $21 \%$ of patient with BHP;59\% in LGPIN and $88 \%$ in HGPIN and $100 \%$ in malignancy. Statistical analysis showed that significantly higher level of tPSA in prostatic malignancy as compared to benign lesion $(\mathrm{p}<0.001)$.

The distribution of patients showed that normal fPSA (0-5 $\mathrm{ng} / \mathrm{ml}$ ) level present in $85 \%$ of patient with BHP; $68 \%$ in LGPIN; $50 \%$ in HGPIN, and $14 \%$ in prostatic malignancy. Statistical analysis showed that significantly higher level of 
fPSA in prostatic malignancy as compared to benign lesion $(\mathrm{p}<0.001)$

Significantly higher levels of tPSA and fPSA were seen in patients with prostatic lesion than normal healthy volunteers $(p<0.001)$, signifying that patient with prostatic lesion have higher levels of tPSA and fPSA as compared to normal healthy population(table no.3).

\section{Discussion}

Prostate cancer is common, potentially deadly, and associated with enormous financial health-care costs. PSA is organ-specific, not cancer-specific and serum levels may be elevated in the presence of $\mathrm{BPH}$, prostatitis and other non-malignant conditions. The usefulness of PSA as an early detector of prostate cancer by itself is questionable,

Table 1: Total PSA distribution in patients with prostatic lesions.

\begin{tabular}{|c|c|c|c|c|c|c|c|}
\hline \multirow{2}{*}{ Prostatic lesions } & & \multicolumn{5}{|c|}{ PSA Level (ng/mL) } & \multirow[b]{2}{*}{ Total } \\
\hline & & $0-5$ & $5.01-10.0$ & $10.1-15.0$ & $15.1-25$ & $>25$ & \\
\hline \multirow{2}{*}{ Benign } & $\mathrm{N}$ & 53 & 23 & 5 & 3 & 12 & 96 \\
\hline & $\%$ & $55.2 \%$ & $24.0 \%$ & $5.2 \%$ & $3.1 \%$ & $12.5 \%$ & $100.0 \%$ \\
\hline \multirow{2}{*}{$\begin{array}{l}\text { Pre-malignant } \\
\text { lesion }\end{array}$} & $\mathrm{N}$ & 1 & 10 & 10 & 8 & 9 & 38 \\
\hline & $\%$ & $2.6 \%$ & $26.3 \%$ & $26.3 \%$ & $21.1 \%$ & $23.7 \%$ & $100.0 \%$ \\
\hline \multirow{2}{*}{ Malignancy } & $\mathrm{N}$ & 0 & 0 & 1 & 0 & 6 & 7 \\
\hline & $\%$ & $0 \%$ & $.0 \%$ & $14.3 \%$ & $.0 \%$ & $85.7 \%$ & $100.0 \%$ \\
\hline \multirow{2}{*}{ Total } & $\mathrm{N}$ & 54 & 33 & 16 & 11 & 27 & 141 \\
\hline & $\%$ & $38.3 \%$ & $23.4 \%$ & $11.3 \%$ & $7.8 \%$ & $19.1 \%$ & $100.0 \%$ \\
\hline
\end{tabular}

Chi-Square test applied. P value 0.001 (Highly significant).

Table 2: Free PSA distribution in patients with prostatic lesions.

\begin{tabular}{|c|c|c|c|c|c|c|}
\hline \multirow{2}{*}{ Prostatic lesions } & & \multicolumn{5}{|c|}{ Free PSA Level (ng/mL) } \\
\hline & & $0-5$ & $5.01-10.0$ & $10.1-15.0$ & $15.1-25$ & Total \\
\hline \multirow{2}{*}{ Benign } & $\mathrm{N}$ & 82 & 7 & 1 & 6 & 96 \\
\hline & $\%$ & $85.4 \%$ & $7.3 \%$ & $1.0 \%$ & $6.3 \%$ & $100.0 \%$ \\
\hline \multirow{2}{*}{ Pre-malignant lesion } & $\mathrm{N}$ & 23 & 10 & 2 & 3 & 38 \\
\hline & $\%$ & $60.5 \%$ & $26.3 \%$ & $5.3 \%$ & $7.9 \%$ & $100.0 \%$ \\
\hline \multirow{2}{*}{ Malignancy } & $\mathrm{N}$ & 1 & 1 & 3 & 2 & 7 \\
\hline & $\%$ & $14.3 \%$ & $14.3 \%$ & $42.9 \%$ & $28.6 \%$ & $100.0 \%$ \\
\hline \multirow{2}{*}{ Total } & $\mathbf{N}$ & 106 & 18 & 6 & 11 & 141 \\
\hline & $\%$ & $75.2 \%$ & $12.8 \%$ & $4.3 \%$ & $7.8 \%$ & $100.0 \%$ \\
\hline
\end{tabular}

Chi-Square test applied. P value 0.001 (Highly significant).

Table 3: Comparison of total PSA and free PSA in patients with prostatic lesions and normal healthy volunteers-

\begin{tabular}{|l|l|l|l|l|l|l|l|}
\hline & \multicolumn{4}{|l}{ Total PSA } & \multicolumn{2}{l|}{ Free PSA } & $\begin{array}{l}\text { P value } \\
\text { (Significance) }\end{array}$ \\
\cline { 2 - 9 } & Mean & SD & Range & Mean & SD & Range & \\
\hline Patients & 16.2783 & 23.00136 & $0.23-124.0$ & 4.5243 & 5.5041 & $0-24.30$ & \\
\hline Control & 2.0386 & 1.25680 & $0.2-5.2$ & 0.8948 & 3.253 & $0.2-3.9$ & $0.001(\mathrm{HS})$ \\
\hline
\end{tabular}

Unpaired t test applied. P value significant if less than 0.05 .

Table 4: Sensitivity and specificity of total PSA and Free PSA in detecting prostatic cancer.

\begin{tabular}{|l|c|c|c|c|c|}
\hline Parameter & Cut off & Sensitivity & Specificity & PPV & NPV \\
\hline Total PSA & $>12.25$ & $100 \%$ & $72 \%$ & $16 \%$ & $100 \%$ \\
\hline Free PSA & $>9.4$ & $85 \%$ & $91 \%$ & $33 \%$ & $99 \%$ \\
\hline
\end{tabular}




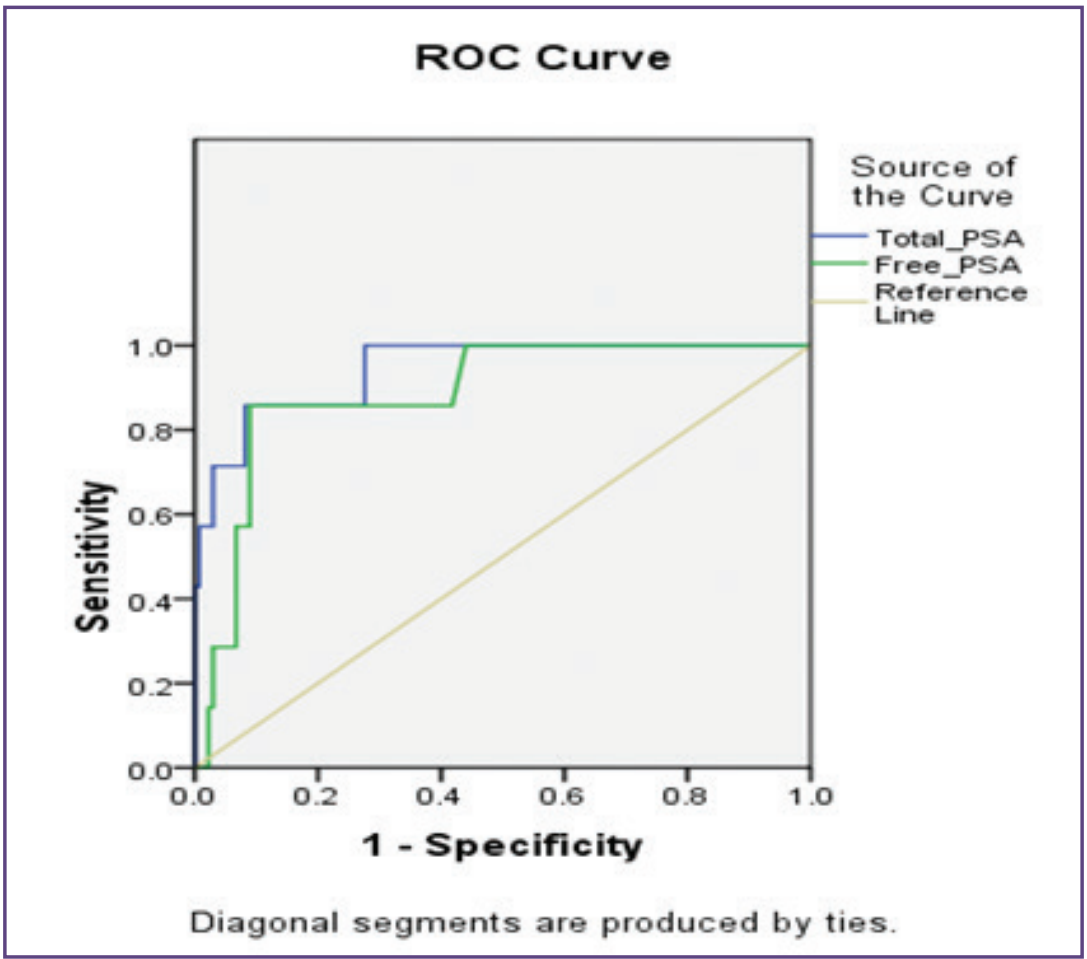

Area under the Curve

\begin{tabular}{|c|c|}
\hline Test Result Variable(s) & Area \\
\hline Total_PSA & .943 \\
\hline Free_PSA & .886 \\
\hline
\end{tabular}

Area under the curve is used for predicting ability of diagnostic test. The higher the value, higher is the predictive ability. Area under curve is interpreted as: 0.50 to $0.75=$ fair, 0.75 to $0.92=$ good, 0.92 to $0.97=$ very good,, 0.97 to $1.00=$ excellent .

Total PSA has very good predictive value as diagnostic test (AUC 0.943).

Free PSA has good predictive value as diagnostic test (AUC 0.886).

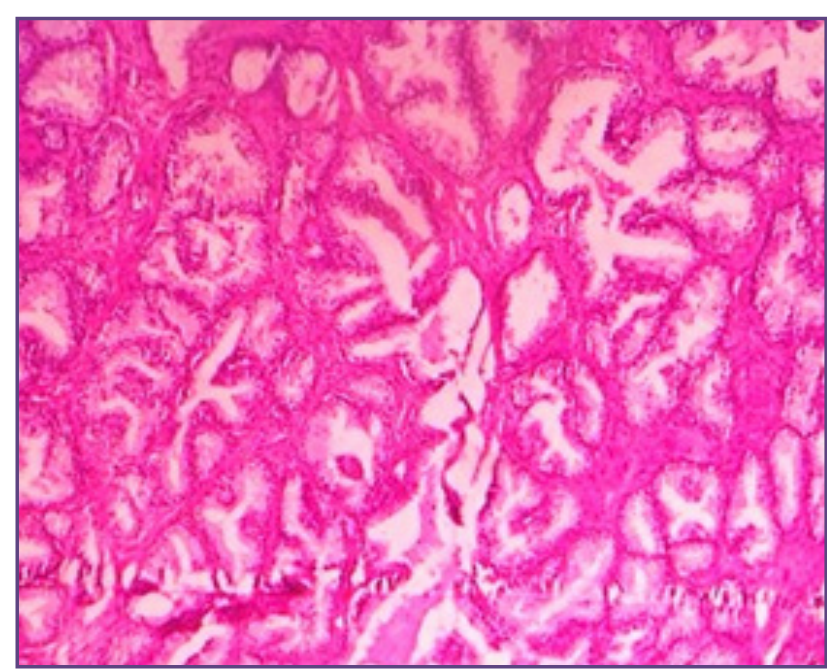

Fig. 2: Benign Prostatic Hyperplasia (H\&E Stain-100X) -increased acini and stroma with double layer lining of epithelium.

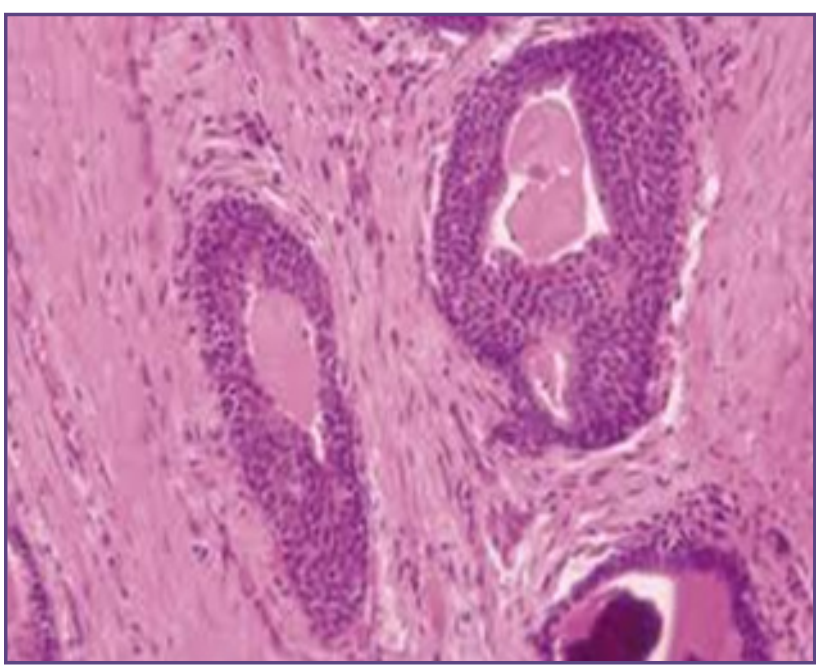

Fig. 3: Low Grade Prostatic Intraepithelial Neoplasia(LGPIN) -multilayering of epithelium with nuclear enlargement (H\&E Stain -100X). 


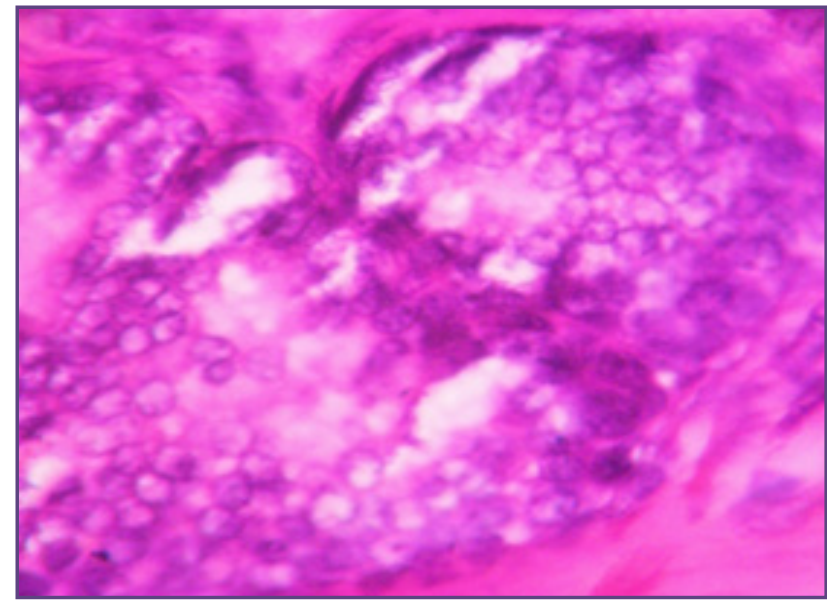

Fig. 4: High Grade Prostatic Intraepithelial Neoplasia (HGPIN) - multilayeringof epithelium with hyperchromatic nuclei (H\&E Stain-400X).

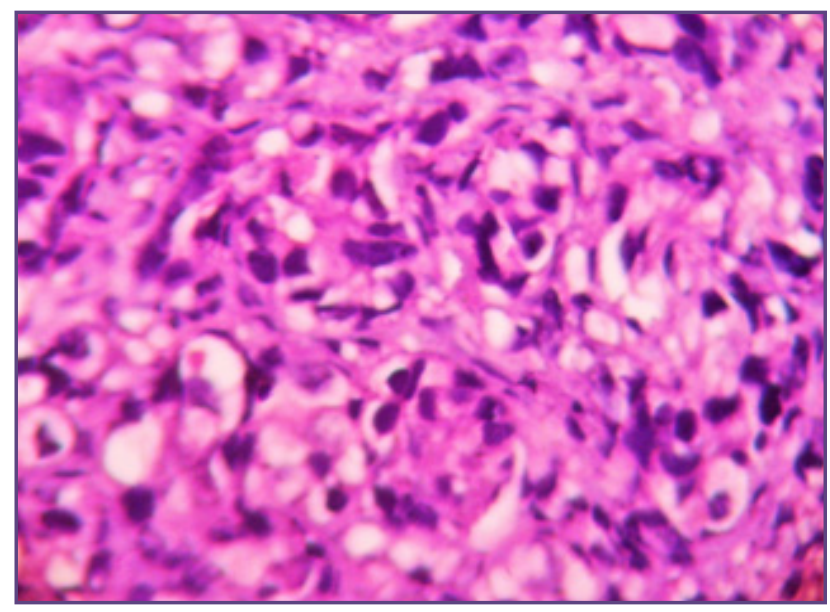

Fig. 5: POORLY DIFFERENTIATED ADENOCARCINOMA OF PROSTATE -GLEASONSCORE3+4;7/10 (H\&E Stain -400X).

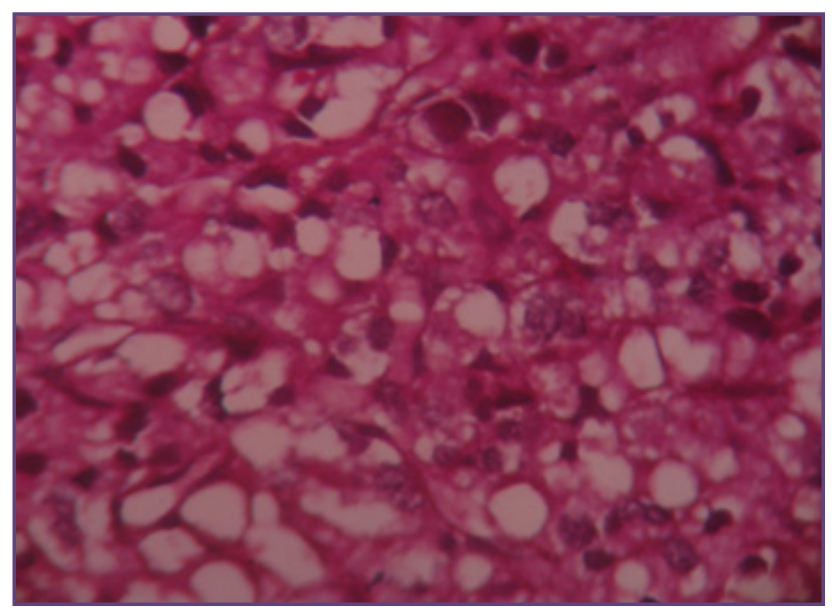

Fig 6 - ADENOCARCINOMA OF PROSTATE-SIGNET RING CELL TYPE; GLEASON SCORE -3+3,6/10 (H\&E Stain-400x). owing to the overlap in PSA values seen in patients with $\mathrm{BPH}$ and in those with organ-confined prostate cancer. The need for an accurate marker is driven by the fear of unnecessary biopsies on the one hand, and the risk of missing a treatable cancer on the other. ${ }^{[5,6,7]}$ Therefore, in our study, we measured two biomarkers (total PSA and free PSA) in 141 patients with prostatic lesion and correlated it with different prostatic lesions; and also attempted to understand an accuracy of PSA cut off variable in various pathological conditions of prostate. Total PSA and free PSA are also measured in equal number of healthy volunteers which were used as a positive control.

Prostate cancer is associated with a lower percentage of free PSA in the serum as compared with benign conditions. fPSA is usually $30 \%$ of the total PSA but in malignancy it is reduced $<25 \%$ of total PSA (tPSA) which is useful to distinguish malignant and benign cases and thus helps in diagnosis of cancer. ${ }^{[8,9]}$ The free PSA has been used to improve the sensitivity of cancer detection when total PSA is in the normal range $(<4 \mathrm{ng} / \mathrm{mL})$ and to increase the specificity of cancer detection when total PSA in the "gray zone" (4.1 to $10 \mathrm{ng} / \mathrm{mL}$ ). The lower the value of free to total PSA in patient with total PSA in the gray zone, the greater is the likelihood that an elevated PSA represents cancer and not BPH. ${ }^{[10-14]}$

Our study showed significantly high levels of tPSA in patients with prostatic lesion than normal healthy volunteers $(p<0.001)$, signifying that patients with prostatic lesions have higher level of tPSA as compared to normal healthy population.Also in our study significantly raised level of fPSA were seen in patients with prostatic lesion and normal healthy volunteers $(p<0.001)$, signifying that patients with prostatic lesion have higher level of fPSA as compared to normal healthy population.

Serum fPSA level ranging from 0.4 to $1.3 \mathrm{ng} / \mathrm{mL}$ is used as reference value in most laboratories. In present study, the fPSA level in patients of BPH ranged from 0.04-24.30 $\mathrm{ng} / \mathrm{mL}$ which was similar to findings by Lakhey et al who reported fPSA range of 04-19.82 ng/mL. ${ }^{[15]}$

$\mathrm{BPH}$ is a heterogenous disease that is characterized histologically by a variable degree of stromal and epithelial hyperplasia. Thus men with a predominance of epithelial hyperplasia are expected to have greater increases in PSA levels than men with predominant stromal hyperplasia. ${ }^{[16]}$ The variation in PSA levels in BPH can also be explained by the detection of various degrees of inflammatory changes detected histologically in TURP specimens. $35.41 \%$ of our BPH patients had histological prostatitis. Lakhey et al reported that $34.6 \%$ of $\mathrm{BPH}$ had histological prostatitis. 
[15] Similarly, Kohnen et al reported that $98.1 \%$ of BPH had histological prostatitis. ${ }^{[17]}$ Blumfeld et al also reported that lymphocytic prostatitis was present in $95 \%$ of TURP specimens. ${ }^{[18]}$ Many reports indicate that the serum PSA level is elevated in patients with clinical acute prostatitis. ${ }^{[19]}$ Lakhey et al show that fPSA of patients with BPH without inflammation and patients with chronic inflammation ranged from normal level to $3.0 \mathrm{ng} / \mathrm{mL}$, while patients with active inflammation had values more than $3.0 \mathrm{ng} / \mathrm{mL}$. Our study showed similar findings. ${ }^{[15]}$

In our study, LGPIN and HGPIN were seen in 22 (15.6\%) and $16(11.34 \%)$ patients respectively. The corresponding tPSA and fPSA levels in LGPIN were $16.32 \mathrm{ng} / \mathrm{ml}$ and 5.12 $\mathrm{ng} / \mathrm{ml}$; slightly elevated than normal, while the levels were above $25.92 \mathrm{ng} / \mathrm{mL}$ and $7.25 \mathrm{ng} / \mathrm{ml}$ in HGPIN. The results of our study are correlating with published literature. ${ }^{[20,21,22]}$ In a study by Lakhey et al, LGPIN was seen in $7.69 \%$ of the 91 patients. Elevated levels of fPSA in HGPIN as compared to LGPIN. ${ }^{[15]}$ Some studies suggest that PIN causes serum PSA elevation, while other studies dispute this relationship. In our study most of the patients with prostatic carcinoma had serum fPSA levels more than 5.0 $\mathrm{ng} / \mathrm{mL} \cdot{ }^{[15,23]}$

In other study, Alpeshpuri $\mathrm{P}$ et al., mean serum PSA values in cases of prostatic hyperplasia with or without dysplasia, prostatitis, well to moderately differentiated adenocarcinoma and poorly differentiated adenocarcinoma were $6.49 \mathrm{ng} / \mathrm{ml}, 5.35 \mathrm{ng} / \mathrm{ml}, 18.92 \mathrm{ng} / \mathrm{ml}$ and $31.6 \mathrm{ng} / \mathrm{ml}$ respectively. ${ }^{[23]}$

Statistical analysis of our study showed significantly higher levels of tPSA in prostatic malignancy as compared to benign lesions $(p<0.001)$ and prostatic intraepithelial neoplasia $(p<0.001)$. Significantly higher level of tPSA was seen in prostatic intraepithelial neoplasia as compared to benign lesions $(\mathrm{p}<0.012)$. However, tPSA and fPSA in one case of benign lesion was high as $78.8 \mathrm{ng} / \mathrm{mL}$ and 24.3 $\mathrm{ng} / \mathrm{mL}$ whereas tPSA and fPSA in some cases of PIN/PCa are as $2.91 \mathrm{ng} / \mathrm{mL}$ and $0.90 \mathrm{ng} / \mathrm{mL}$ respectively. Similar overlap has been witnessed in a number of studies using total PSA values, making selection of an optimum cut off value difficult.

The American Cancer Society estimated sensitivity of a PSA at cut-off of $4.0 \mathrm{ng} / \mathrm{mL}$ as $21 \%$ for detecting any prostate cancer and $51 \%$ for detecting high-grade cancers (Gleason $\geq 8$ ). Using a cut-off of $3.0 \mathrm{ng} / \mathrm{mL}$ increased these sensitivities to 32 and $68 \%$, respectively. The estimated specificity was $91 \%$ for a PSA cut-off of $4.0 \mathrm{ng} / \mathrm{mL}$ and $85 \%$ for a $3.0 \mathrm{ng} / \mathrm{mL}$ cut-off. PSA has poorer discriminating ability in men with symptomatic benign prostatic hyperplasia Overall, the positive predictive value for a PSA level $>4.0 \mathrm{ng} / \mathrm{mL}$ is approximately $30 \%$, meaning that slightly less than one in three men with an elevated PSA will have prostate cancer detected on biopsy. For PSA levels between 4.0 and $10.0 \mathrm{ng} / \mathrm{mL}$, the positive predictive value is about $25 \%$. However, nearly $75 \%$ of cancers detected within the - gray zone of PSA values between 4.0 and 10.0 $\mathrm{ng} / \mathrm{mL}$ are organ confined and potentially curable. ${ }^{[24]}$ In our data, though there was overlap of tPSA and fPSA values between $\mathrm{BPH}$ and $\mathrm{PCa}$, yet it is significantly higher in case of PIN and PCa. Clinical sensitivity of tPSA to distinguish $\mathrm{PCa}$ from $\mathrm{BPH}$ is $100 \%$ at cut-off value of $12.25 \mathrm{ng} / \mathrm{mL}$. At the cut-off value of the specificity remains low with only $72 \%$. Similarly, clinical sensitivity of fPSA to distinguish $\mathrm{PCa}$ from $\mathrm{BPH}$ is $85 \%$ at cut-off value of $9.4 \mathrm{ng} / \mathrm{mL}$. At the cut-off value of the specificity is higher $91 \%$.

Lakhey et al too reported overlap of fPSA values between $\mathrm{BPH}$ and $\mathrm{PCa}$ with statistically higher level in PCa. Clinical sensitivity of fPSA to distinguish $\mathrm{PCa}$ from $\mathrm{BPH}$ is $100 \%$ at cut-off value of $1.81 \mathrm{ng} / \mathrm{mL} .{ }^{[15]}$ However, at the cut-off value the specificity remains poor with only $49 \%$. By raising the cut-off value to $12.65 \mathrm{ng} / \mathrm{mL}$, specificity can improve to $94 \%$, limiting sensitivity to only $60 \%$. It was further noticed that use of cut-off value of $5.0 \mathrm{ng} / \mathrm{mL}$ will be optimum for clinical use to differentiate $\mathrm{PCa}$ with $\mathrm{BPH}$ as, sensitivity of $88.8 \%$ and specificity of $90.2 \%$ can be achieved.(Table no 4)

Considering, the higher sensitivity of tPSA at cut-off value of $12.25 \mathrm{ng} / \mathrm{mL}$, tPSA will be optimum for clinical use to differentiate PCa with BPH as a screening tool and fPSA, owing to its higher specificity at cut-off value of $9.4 \mathrm{ng} / \mathrm{mL}$ to be used to confirm the diagnosis.

Our study has few limitations: - First, we excluded the patients with acute retention of urine which are expected to cause elevation in PSA levels that may confound the results. Second, histologic correlation in our study was done on TURP specimens and not prostatectomy specimens. Third, the study was exploratory as it was not powered to detect the pre-determined difference between different groups. Large sample size is recommended to generalize the findings of our study. The cut off value of tPSA was $12.25 \mathrm{ng} / \mathrm{ml}$ (not in gray zone) as as the malignant cases were few i.e 7 in 141 in our present study.

\section{Conclusion}

Serum tPSA and fPSA are elevated marginally in patients with $\mathrm{BPH}$ without inflammation and patients with chronic inflammation. The higher grade lesions (HGPIN and PCa) are associated with tPSA and fPSA values more than 25.92 $\mathrm{ng} / \mathrm{ml}$ and $7.25 \mathrm{ng} / \mathrm{ml}$. Considering, the higher sensitivity 
of tPSA at cut-off value of $12.25 \mathrm{ng} / \mathrm{mL}$, tPSA will be optimum for clinical use to differentiate $\mathrm{PCa}$ with $\mathrm{BPH}$ as a screening tool and fPSA, owing to its higher specificity at cut-off value of $9.4 \mathrm{ng} / \mathrm{mL}$ can be used to confirm the diagnosis. The optimal cut-off value of PSA is unclear and depends upon whether optimal sensitivity or specificity. The higher the cut-off value,greater the sensitivity but lesser the specificity. Free PSA may be useful for risk stratification in men with prostate cancer.

\section{Acknowledgements}

The authors thank the staff of Department of Pathology N.K.P.Salve Medical College for the support and technical assistance.

\section{Funding}

No funding was needed for the study.

\section{Competing Interest}

There is no competing interest.

\section{References}

1. Oesterling JE, Jacobsen SJ, Chute CG, Guess HA, Girman CJ, Panser LA, et al. Serum prostate- specific antigen in a community-based population of healthy men: Establishment of Age-specific Reference Ranges. JAMA.1993;270:860-4.

2. Oesterling, JE. Prostate-specific antigen: a critical assessment of the most useful tumour marker for adenocarcinoma of the prostate. J Urol 1991;145:907-23.

3. Chan DW, Booth RA, Diamansid EP. Tumor marker. In, Brutis CA, Ashwood ER, Bruns DE, editors. Teitz textbook of clinical chemistry and molecular diagnostics. 4th edition. New Delhi:Elsevier; 2006.p.2053-95. 133.

4. Oesterling JE, Jacobsen SJ, Chute CG et al. Serum prostatespecific antigen in a community-based population of healthy men. Establishment of age-specific reference ranges. JAMA. 2003; 270:860.

5. Stamey TA, Caldwell M, McNeal JE, et al. The prostate specific antigen era in the United States is over for prostate cancer: what happened in the last 20 years? J Urol. 2004;172:1297-1301.

6. Thompson IM, Ankerst DP, Chi C, et al. Operating characteristics of prostate-specific antigen in men with an initial PSA level of $3.0 \mathrm{ng} / \mathrm{ml}$ or lower. JAMA. 2005;294:6670 .

7. Schroder FH, Bangma CH, Roobol MJ. Is it necessary to detect all prostate cancers in men with serum PSA levels $<3.0 \mathrm{ng} / \mathrm{ml}$ ? A comparison of biopsy results of PCPT and outcome-related information from ERSPC. Eur Urol. 2008;53:901-908.

8. Mikolajczyk SD, Marks LS, Partin AW, Rittenhouse HG. Free prostate-specific antigen in serum is becoming more complex. Urology. 2002; 59:797.
9. Balk SP, Ko YJ, Bubley GJ. Biology of prostate-specific antigen. J Clin Oncol. 2003; 21:383.

10. Lilja H, Christensson A, Dahlen U, et al. Prostate-specific antigen in serum occurs predominantly in complex with alpha 1-antichymotrypsin. Clin Chem 1991;37:1618.

11. Christensson A, Laurell CB, Lilja H. Enzymatic activity of prostate-specific antigen and its reactions with extracellular serine proteinase inhibitors. Eur J Biochem 1990;194:755.

12. Christensson A, Bjork T, Nilsson O, et al. Serum prostate specific antigen complexed to alpha 1-antichymotrypsin as an indicator of prostate cancer. J Urol 1993;150:100.

13. Catalona WJ, Partin AW, Slawin KM et al. Use of the percentage of free prostate-specific antigen to enhance differentiation of prostate cancer from benign prostatic disease: a prospective multicenter clinical trial. JAMA. 1998;279:1542.

14. Luderer AA, Chen YT, Soriano TF, et al. Measurement of the proportion of free to total prostate-specific antigen improves diagnostic performance of prostate-specific antigen in the diagnostic gray zone of total prostate-specific antigen. Urology 1995;46:187.

15. Lakhey M, Ghimire R, Shrestha R, Bhatta AD. Correlation of serum free prostate-specific antigen level with histological findings in patients with prostatic disease. Kathmandu Univ Med J (KUMJ). 2010 Apr-Jun;8(30):158-63.

16. McNeal J. Pathology of Benign Prostatic Hyperplasia. Insight into Etiology. In: Lepor H, Walsh PC (eds). The Urologic Clinics of North America, 17th edn. WB Saunders Company: Philadelphia, 1990, pp 477-486.

17. Kohnen PW, Drach GW. Pattern of infl ammation in prostatic hyMikolajczyk SD, Marks LS, Partin AW, Rittenhouse HG. Free prostate-specific antigen in serum is becoming more complex. Urology. 2002; 59:797. perplasia: a histologic and bacteriologic study. J Urol. 1979;121:755-60. 152

18. Blumenfeld W, Tucci S, Narayan P. Incidental lymphocytic prostatitis: selective involvement with nonmalignant glands. Am J Surg Pathol. 1992;16:975-81.

19. T. Malati, G. Rajani Kumari, P.V.L.N. Murthy Ch. Ram Reddy, B. Surya Prakash.Prostate Specific Antigen In Patients Of Benign Prostate Hypertrophy And Carcinoma Prostate. Indian Journal of Clinical Biochemistry 2006; 21 (1): $34-40$.

20. Kehinde EO, Sheikh M, Mojimoniyi OA, Francis I, Anim JT, Nkansa-Dwamena D, Al-Awadi KA. High serum prostatespecific antigen levels in the absence of prostate cancer in Middle-Eastern men: the clinician's dilemma. BJU Int. 2003 May; 91(7):618-22.

21. Bostwick DG, Brawer MK. Prostatic intraepithelial neoplasia and early invasion in prostate cancer. Cancer. 1987;59:788-794.

22. Kim HL, Yang XJ. Prevalence of high-grade prostatic intraepithelial neoplasia and its relationship to serum prostate specific antigen. Int Braz J Urol. 2002;28:413-417. 
23. Goswami AP, Rupala G, Goswami NN. Serum PSA level in Prostatic lesions with Histopathological correlation in Gujarat. NJIRM. 2011; 2(4):33-8.
24. Meigs JB, Barry MJ, Oesterling JE, Jacobsen SJ. Interpreting results of prostate-specific antigen testing for early detection of prostate cancer. J Gen Intern Med. 1996;11:505.

*Corresponding author:

Dr. Shruti Amit Deshpande, AssistantProfessor, Department of Pathology, Mamata Medical College, Rotary Nagar, Khammam, Telangana, India.5007002.

Phone: +91 963779576

Email: drayachit@gmail.com

Financial or other Competing Interests: None. 